\title{
Partial Oxidation of Propylene over As Prepared and Acid Enriched $\mathrm{Bi}_{2} \mathrm{Mo}_{1-\mathrm{x}} \mathrm{W}_{\mathrm{x}} \mathrm{O}_{6}$ System
}

\author{
Shambhu S. Parab*, S.J. Naik, A.V. Salker \\ Department of Chemistry, Goa University, Goa 403 206, India
}

Received: $16^{\text {th }}$ September 2016; Revised: $1^{\text {st }}$ December 2016; Accepted: $9^{\text {th }}$ March 2017

\section{Abstract}

The compounds $\mathrm{Bi}_{2} \mathrm{Mo}_{1-\mathrm{x}} \mathrm{W}_{\mathrm{x}} \mathrm{O}_{6}(x=0.0,0.2$, and 0.4) were obtained through a Citrate sol-gel process. Thermogravimetric differential thermal analysis (TG-DTA), X-ray diffraction (XRD), Scanning electron microscopy (SEM) and X-ray photoelectron spectroscopy (XPS) techniques were used for characterization. Reitveld refinement of the XRD data confirmed the crystal structure of all the compositions to be orthorhombic, having Pca2 1 space group. XPS studies indicated the presence of +6 as well as +4 oxidation state for Mo. Surface acid enrichment of all the catalysts was done and monitored by $\mathrm{NH}_{3}-\mathrm{TPD}$ studies. Partial oxidation of propylene was studied over all the compounds. The $\mathrm{W}$ doping was found to increase the catalytic activity. Moreover, as-prepared catalysts and acid enriched catalysts were compared for their catalytic activity wherein, acid-enriched catalysts showed the improved conversion of propylene without hampering the product selectivity profile. Copyright (C) 2017 BCREC Group. All rights reserved

Keywords: Ammonia TPD; $\mathrm{Bi}_{2} \mathrm{Mo}_{1-\mathrm{x}} \mathrm{W}_{\mathrm{x}} \mathrm{O}_{6}$; Partial oxidation; Structural studies

How to Cite: Parab, S.S., Naik, S.J., Salker, A.V. (2017). Partial Oxidation of Propylene over as Prepared and Acid Enriched $\mathrm{Bi}_{2} \mathrm{Mo}_{1-\mathrm{x}} \mathrm{W}_{\mathrm{x}} \mathrm{O}_{6}$ System. Bulletin of Chemical Reaction Engineering \& Catalysis, 12 (2): 197-205 (doi:10.9767/bcrec.12.2.702.197-205)

Permalink/DOI: http://dx.doi.org/10.9767/bcrec.12.2.702.197-205

\section{Introduction}

Bismuth-Molybdenum oxides have garnered great amount of attention due to their wide range of applications. Especially the three phases, $\quad \alpha-\mathrm{Bi}_{2} \mathrm{Mo}_{3} \mathrm{O}_{12}, \quad \beta-\mathrm{Bi}_{2} \mathrm{Mo}_{2} \mathrm{O}_{9}, \quad$ and $\quad \gamma$ $\mathrm{Bi}_{2} \mathrm{MoO}_{6}$, have remained focal points in the study of partial oxidation of light hydrocarbons like propylene for many years. The mixed metal oxides containing $\mathrm{Bi}$ and $\mathrm{Mo}$ as base components have been the mainstay of industrial catalysts for partial oxidation [1]. Researchers have thoroughly studied the mixtures of aforementioned three phases as a single catalyst system to study the synergy effects $[2,3]$. Most of

* Corresponding Author.

E-mail: shambhu@unigoa.ac.in the authors credit $\gamma$ phase for the oxygen transport [4,5], whereas $\alpha$ and $\beta$ phases are credited for their possession of more number of active sites for propylene chemisorption [6,7]. Recently Grunwaldt et al. [8] have prepared Bi-Mo oxides by flame pyrolysis with enhanced surface area. They have rated the three phases in the following order $\beta>\gamma>\alpha$, based on their activity for partial oxidation of propylene.

Among the above three phases, $\gamma-\mathrm{Bi}_{2} \mathrm{MoO}_{6}$ is the most studied compound due to its interesting properties such as dielectric capacity, ion conductivity, luminescence and catalysis [9]. Some researchers have claimed $\mathrm{Bi}_{2} \mathrm{MoO}_{6}$ to be the least efficient phase for partial oxidation reaction $[2,10]$, but some have labeled it as having activity that is similar to $\mathrm{Bi}_{2} \mathrm{Mo}_{3} \mathrm{O}_{12}[11,12]$. The $\mathrm{Bi}_{2} \mathrm{MoO}_{6}$ crystal structure is made up of alter- 
nating layers of $\left[\mathrm{Bi}_{2} \mathrm{O}_{2}\right]^{2+}$ and $\left[\mathrm{MoO}_{2}\right]^{2+}$, wherein the octahedral $\mathrm{MoO}_{6}$ are linked to each other by corner sharing [13]. The layered structure of $\mathrm{Bi}_{2} \mathrm{MoO}_{6}$ is responsible for its high ionic conductivity, which is highest among the three phases [4]. Lattice oxide participation is an important factor which determines the active sites for partial oxidation [14] therefore ionic conductivity of a catalyst is considered very important in these reactions [15]. According to the most accepted mechanism [16], propylene gets chemisorbed on an unsaturated Mo site accompanied by an allylic hydrogen abstraction by a $\mathrm{Bi}$ site to form an allyl radical. To this allyl radical, oxygen is inserted, forming acrolein. Inserted mobile oxygen is accepted to be associated with the Mo site. It has been reported earlier in the literature that the energy needed to remove oxygen from the Mo site is very low as compared to the Bi site [17]. Therefore, Mo acts as a channel for the transport of oxygen in the crystal lattice.

Considering the above facts, in the present work $\mathrm{W}$ was partially substituted in place of Mo to analyze its influence on structure, chemical environment and physical properties. These effects in turn were expected to influence partial oxidation of propylene. The structural parameters of solid solutions were refined using Reitveld refinement. Grasselli et al. [18] have pointed out that the introduction of $\mathrm{NH}_{3}$ in the feed gas composition along with the propylene and $\mathrm{O}_{2}$ decreased the catalytic performance considerably, this was attributed to the coordination of $\mathrm{NH}_{3}$ to the unsaturated Mo sites thereby decreasing propylene chemisorptions, an unsaturated Mo site in this case acts as an acidic site. In view of this, the compounds were treated with a very dilute mineral acid; this was expected to bring a change in the surface acidic character of the compounds. The surface acidity was duly characterized by the $\mathrm{NH}_{3}$-TPD studies.

\section{Materials and Methods}

\subsection{Materials}

$\mathrm{AR}$ grade reagents like $\mathrm{Bi}\left(\mathrm{NO}_{3}\right)_{3} .5 \mathrm{H}_{2} \mathrm{O}$, $\mathrm{H}_{2} \mathrm{WO}_{4}$ and $\left(\mathrm{NH}_{4}\right)_{6} \mathrm{Mo}_{7} \mathrm{O}_{24}$ were bought from Aldrich. Citric acid was purchased from ThomasBaker Ltd., while propylene (99.5\% purity) was purchased from Bhoruka Gases Ltd., Bengaluru, India. Whereas $\mathrm{H}_{2}(99.97 \%)$, zero air, $\mathrm{O}_{2}(>99.5 \%), \mathrm{N}_{2}(99.998 \%)$, and $\mathrm{Ar}(99.9995 \%)$ were purchased from Govind Poy Oxygen Ltd., Goa, India.

\subsection{Catalyst preparation}

Preparation of $\mathrm{Bi}_{2} \mathrm{Mo}_{1-\mathrm{x}} \mathrm{W}_{\mathrm{x}} \mathrm{O}_{6}(\mathrm{x}=0.0,0.2$, 0.4) series was carried out by the Pechini method [19]. This method leads to a better homogeneous mixing and minimizes phase segregation as compared to the traditional solid state reaction. Citrate with a hydroxyl and three carboxylate groups form complexes with metal ions through co-ordination and is known to control the microstructure of the materials [20]. Weighed quantities of the required chemicals were dissolved in the aqueous solution of citric acid with stirring, the mixture was heated to $80{ }^{\circ} \mathrm{C}$ until a transparent solution was obtained, and ethylene glycol was added to facilitate the polymerization by polyesterification reaction. Solution was then heated to $90-100{ }^{\circ} \mathrm{C}$ with stirring until a clear gel was obtained. The obtained gel was dried at $150{ }^{\circ} \mathrm{C}$ for 5 hours. Probable sintering temperature was found out by subjecting the solid precursor to TG-DTA analysis.

The $\mathrm{Bi}_{2} \mathrm{Mo}_{1-\mathrm{x}} \mathrm{W}_{\mathrm{x}} \mathrm{O}_{6}(\mathrm{x}=0.0,0.2$, and 0.4) polycrystalline compounds were then obtained by decomposing the carbonaceous precursors by heat treatment at $350{ }^{\circ} \mathrm{C}$ for four hours at the heating rate of $3{ }^{\circ} \mathrm{C} /$ minute. The samples were further heated to $650{ }^{\circ} \mathrm{C}$ for 6 hours to get monophasic compositions. These compounds are called 'as-prepared' compounds in the further discussions. Acid enriched catalysts were prepared as reported in our previous work [21] by dipping the catalysts in a solution of 0.005 $\mathrm{M} \mathrm{HNO}_{3}$ for 1 hour at ambient temperature. After filtration, the residue was heated at 110 ${ }^{\circ} \mathrm{C}$ for 4 hours and finally at $450{ }^{\circ} \mathrm{C}$ for 1 hour in air.

\subsection{Catalyst characterization}

Thermal studies (TG-DTA) were performed on TG/DTA NETZSCH STA 409 PC instrument. The heating was carried out in air at the rate of $10^{\circ} \mathrm{C} / \mathrm{min}$ to get an idea of the decomposition of the precursor. The phase identification of the products was done employing RIGAKU ULTIMA IV X-ray diffractometer with $\mathrm{Cu}-\mathrm{Ka}$ radiation filtered through $\mathrm{Ni}$ absorber. The XRD data was refined with Reitveld refinement using Fullprof-2K software package [22]. Surface morphology was examined by using JEOL model 5800LV Scanning electron microscope operating at $300 \mathrm{kV}$. Surface area measurements were done on SMART SORB $90 / 91$ at $77 \mathrm{~K}$ by $\mathrm{N}_{2}$ adsorption. X-Ray photoelectron spectroscopy on selected samples was recorded on ESCA-3 Mark II spectrometer 
(VSW, UK). $\mathrm{NH}_{3}$ TPD studies were done on MICROMERITICS AUTOCHEM 2910 setup equipped with a TCD detector.

\subsection{Catalytic tests}

Partial oxidation of propylene was undertaken in a continuous flow fixed bed glass reactor. Each time, $2.0 \mathrm{~g}$ of the compound was sandwiched between the two layers of the quartz wool. The catalyst was activated with oxygen $(250 \mathrm{~mL} / \mathrm{h})$ in $\mathrm{N}_{2}$ at $150{ }^{\circ} \mathrm{C}$ for half an hour to drive off any adsorbed gases. The activity was determined employing the feed gas compositions of $5 \%$ propylene, $5 \%$ oxygen in nitrogen. The catalytic tests were done in the temperature range from $250{ }^{\circ} \mathrm{C}$ to $450{ }^{\circ} \mathrm{C}$. The gas flow rates were controlled by mass flow meters and precision needle valves. Reactants and products were determined employing online gas chromatograph. Propylene, acrolein, acetaldehyde and $\mathrm{CO}_{2}$ were detected on Flame ionization detector (FID) using Porapak-Q column, whereas $\mathrm{CO}$ and $\mathrm{O}_{2}$ were monitored on Thermal conductivity detector (TCD) using Molecular sieve-13 x column. High purity $\mathrm{H}_{2}$ and zero air cylinders were used for FID flame. Argon was used as a carrier gas for the GC. Column oven was kept at $140{ }^{\circ} \mathrm{C}$; whereas injector and both the detectors (FID and TCD) were operated at $160{ }^{\circ} \mathrm{C}$.

\section{Results and Discussion}

\subsection{Thermal studies}

The TG/DTA profile of $\mathrm{Bi}_{2} \mathrm{MoO}_{6}$ precursor is shown in Figure 1. The citrate precursor showed mass loss in three distinguishable re-

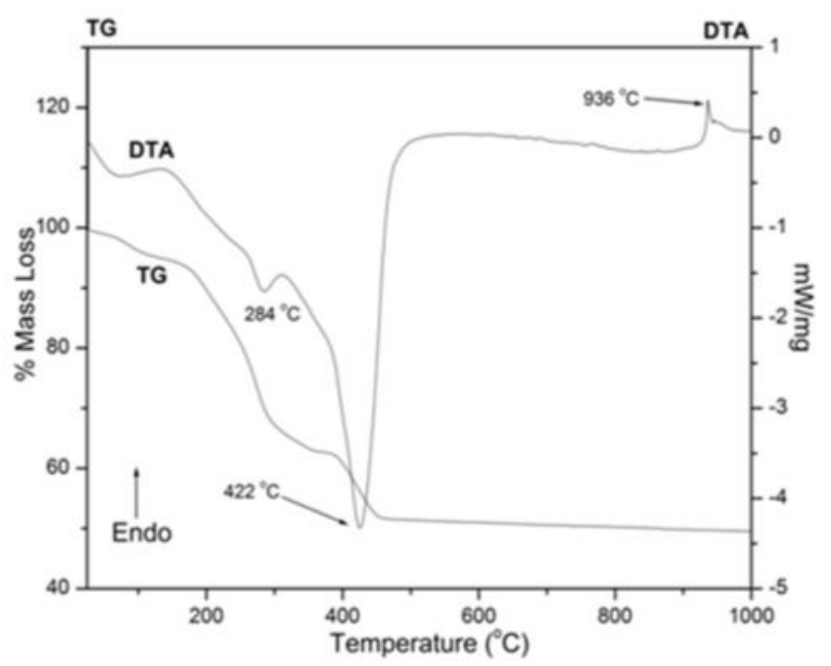

Figure 1. TG/DTA curve of $\mathrm{Bi}_{2} \mathrm{MoO}_{6}$ precursor gions having major exothermic peak at $422^{\circ} \mathrm{C}$. Most of the overall mass loss corresponds to the removal of $\mathrm{H}_{2} \mathrm{O}$ and decompositions of the organic matter. The mass loss region from 30$200{ }^{\circ} \mathrm{C}$ indicates loss of physisorbed and constitutional water from the precursor. A small endothermic peak at $100{ }^{\circ} \mathrm{C}$ is due to the loss of this water. The mass loss in the region from $200-400{ }^{\circ} \mathrm{C}$ corresponds to the initial decomposition of organic moieties, which is characterized by an exothermic peak at $284{ }^{\circ} \mathrm{C}$ in the DTA curve. The mass loss region from 400 $530{ }^{\circ} \mathrm{C}$ is due to the decomposition of remaining organic matter. The strong exothermic peak at $422{ }^{\circ} \mathrm{C}$ is due to the redox decomposition of carboxylate and nitrate moieties leading to the evolution of Carbon oxides and NOx. No signals were observed in TG or DTA curve in the temperature region from 530 to $900{ }^{\circ} \mathrm{C}$. Based on these observations the compounds were finally sintered at $650{ }^{\circ} \mathrm{C}$. A strong endothermic peak observed at $936{ }^{\circ} \mathrm{C}$ indicated the melting point of $\mathrm{Bi}_{2} \mathrm{MoO}_{6}$.

\subsection{Structural studies}

X-Ray diffractograms of $\mathrm{Bi}_{2} \mathrm{Mo}_{1-\mathrm{x}} \mathrm{W}_{\mathrm{x}} \mathrm{O}_{6}(\mathrm{x}=$ $0.0,0.2$, and 0.4) compounds are shown in the Figure 2. The observed $d$-spacing and peak intensities of the pristine compound matched well with the JCPDS data (Card No. 21-0102). The crystallographic refinement parameters are given in Table 1. A refined data was obtained by varying both profile and structural parameters using Rietveld refinement. The structure having space group, $\mathrm{Pca} 2_{1}$ with $a=$ 5.4822, $b=16.1986$, and $c=5.5091 \AA$ was used with the known coordinates of the phase from

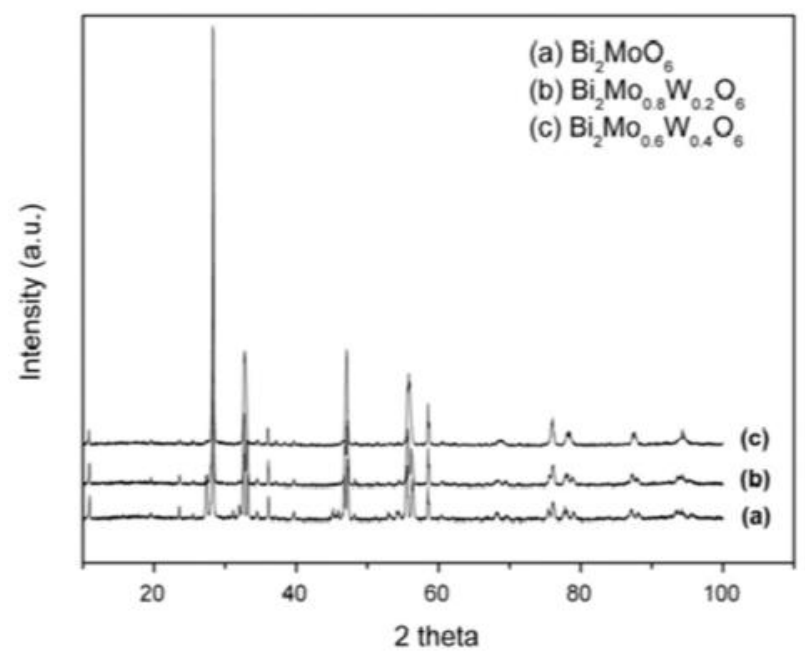

Figure 2. X-ray diffraction patterns of $\mathrm{Bi}_{2} \mathrm{Mo}_{1-\mathrm{x}} \mathrm{W}_{\mathrm{x}} \mathrm{O}_{6}$ 
the literature [23]. As $\mathrm{W}^{+6}$ ion $(60 \mathrm{pm})$ is not significantly larger in size than $\mathrm{Mo}^{+6}$ ion (59 $\mathrm{pm}$ ), it was assumed that $\mathrm{W}$ substitution will not alter the crystal structure of $\mathrm{Bi}_{2} \mathrm{MoO}_{6}$ considerably. Full occupancy was assigned to oxygen and bismuth during the refinement. The occupancy of molybdenum and tungsten was refined considering their stoichiometric amount using Winplotr [22]. Both experimental and calculated profiles of $\mathrm{Bi}_{2} \mathrm{Mo}_{0.6} \mathrm{~W}_{0.4} \mathrm{O}_{6}$ are shown in Figure 3. The corresponding difference in the Fourier map is flat providing an unequivocal verification of the structure. The refinements of these doped compounds are being reported for the first time on polycrystalline materials.

The important observations that can be deduced from the refinement are: (a) the crystal volume has increased linearly with the addition of $\mathrm{W}$, (b) due to $\mathrm{W}$ insertion the atomic positions have got altered as compared to pristine $\mathrm{Bi}_{2} \mathrm{MoO}_{6}$, (b) the Mo and $\mathrm{W}$ contents are found to be in line with molecular formula of the com-

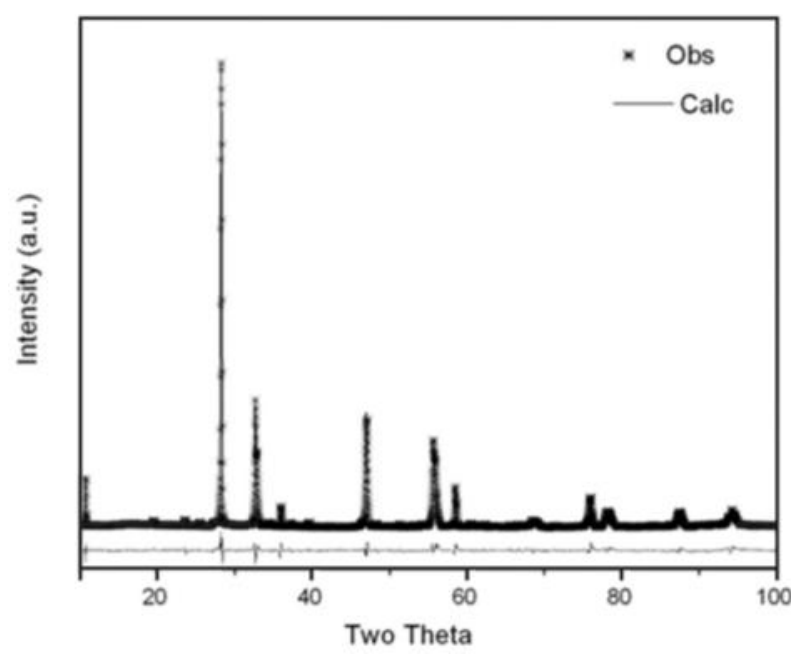

Figure 3. Representative experimental (*) and calculated (solid line) X-ray diffraction profiles of $\mathrm{Bi}_{2} \mathrm{Mo}_{0.6} \mathrm{~W}_{0.4} \mathrm{O}_{6}$. The difference profile is located at the bottom of the profiles pound, (c) the occupancies of oxygen in $\mathrm{MoO}_{6}$ and octahedral $\mathrm{WO}_{6}$ are found to be low; the oxygen vacancies are expected to be located around $\mathrm{MoO}_{6}$ and $\mathrm{WO}_{6}$ octahedra [24].

\subsection{SEM and XPS studies}

The surface area values are reported in Table 2. The surface area did not show a trend as such, but the W inserted compositions showed little higher surface area than pristine $\mathrm{Bi}_{2} \mathrm{MoO}_{6}$. The surface area values obtained are reported to be the characteristic of such compounds [25]. The SEM images of sintered $\mathrm{Bi}_{2} \mathrm{MoO}_{6}$ and $\mathrm{Bi}_{2} \mathrm{Mo}_{0.6} \mathrm{~W}_{0.4} \mathrm{O}_{6}$ are shown in Figures 4 (a) and 4 (b), respectively. Both pristine and doped compounds showed porous flake like morphological features.

XPS studies confirmed the presence of all three metal components without any impurities. XPS spectra of $\mathrm{Bi}_{2} \mathrm{Mo}_{0.6} \mathrm{~W}_{0.4} \mathrm{O}_{6}$ are presented in Figure 5. The $\mathrm{Bi} 4 \mathrm{f}_{5 / 2}$ and $\mathrm{Bi} 4 \mathrm{f}_{7 / 2}$ spin-orbit splitting photoelectrons are located at 164.4 and $159.1 \mathrm{eV}$, respectively as displayed in Figure 5a confirming the presence of $\mathrm{Bi}^{3+}$ in the crystal lattice. Figure 5 (b) shows W $4 \mathrm{f}_{7 / 2}$ and $\mathrm{W} 4 \mathrm{f}_{5 / 2}$ spin-orbit splitting photoelectrons from octahedral $\mathrm{WO}_{6}$ which showed binding energies at 35.20 and $36.60 \mathrm{eV}$, respectively. A typical Mo 3d spectrum is displayed in Figure 5 (c). The Mo 3d5/2 binding energy peaks were seen between 232.4 and $235.8 \mathrm{eV}$ denoting $\mathrm{Mo}^{+6}$ species. The peak at $229.4 \mathrm{eV}$ is assigned to the $\mathrm{Mo}^{+4}$, confirming that there are two oxidation states present for molybdenum. Except

Table 2. BET surface area of $\mathrm{Bi}_{2} \mathrm{Mo}_{1-\mathrm{x}} \mathrm{W}_{\mathrm{x}} \mathrm{O}_{6}$ compounds. $(\mathrm{x}=0.0, \mathrm{x}=0.2, \mathrm{x}=0.4)$

\begin{tabular}{lc}
\hline Catalyst & Surface area $\left(\mathrm{m}^{2} / \mathrm{g}\right)$ \\
\hline $\mathrm{Bi}_{2} \mathrm{MoO}_{6}$ & 2.0 \\
$\mathrm{Bi}_{2} \mathrm{Mo}_{0 .} \mathrm{Mo}_{0.2} \mathrm{O}_{6}$ & 2.6 \\
$\mathrm{Bi}_{2} \mathrm{Mo}_{0.6} \mathrm{~W}_{0.4} \mathrm{O}_{6}$ & 2.3 \\
\hline
\end{tabular}

Table 1. Crystallographic refinement parameters of $\mathrm{Bi}_{2} \mathrm{Mo}_{1-\mathrm{x}} \mathrm{W}_{\mathrm{x}} \mathrm{O}_{6}$

\begin{tabular}{lccc}
\hline \multirow{2}{*}{$\begin{array}{c}\text { Crystallographic } \\
\text { parameters }\end{array}$} & \multicolumn{3}{c}{ Compositions } \\
\cline { 2 - 4 } & $\mathrm{Bi}_{2} \mathrm{MoO}_{6}$ & $\mathrm{Bi}_{2} \mathrm{Mo}_{0.8} \mathrm{~W}_{0.2} \mathrm{O}_{6}$ & $\mathrm{Bi}_{2} \mathrm{Mo0}_{0.6} \mathrm{~W}_{0.4} \mathrm{O}_{6}$ \\
\hline & 1.5418 & 1.5418 & 1.5418 \\
Crystal system & Orthorhombic & Orthorhombic & Orthorhombic \\
Space group & Pca2 & Pca2 & Pca $2_{1}$ \\
$\mathrm{a}(\AA)$ & 5.4835 & 5.4196 & 5.4419 \\
$\mathrm{~b}(\AA)$ & 16.1955 & 16.4832 & 16.4237 \\
$\mathrm{c}(\AA)$ & 5.5045 & 5.4740 & 5.4472 \\
$\mathrm{~V}\left(\AA^{3}\right)$ & 488.839 & 489.006 & 489.529 \\
$\mathrm{CHI} I^{* * 2}$ & 3.31 & 4.94 & 5.54 \\
\hline
\end{tabular}


for the occurrence of $\mathrm{Mo}^{+4}$, all the above observations are in accordance with the reported XPS studies [25,26]. The occurrence of $\mathrm{Mo}^{+4}$ in the composition can be attributed to the residual carbon adhering intimately to the material's surface, this carbon may get oxidized by taking oxygen from the lattice thus reducing $\mathrm{Mo}^{+6}$ in the process.

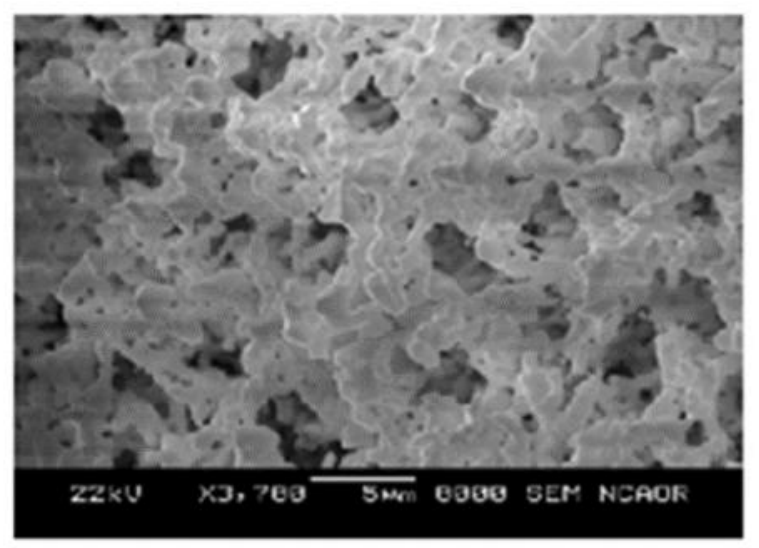

(a)
Figure 5(d) presents XPS peak for the O species, attributed to crystal lattice oxygen and adsorbed oxygen [27,28]. In the literature, XPS is considered to be a potent means to estimate oxygen mobility in the crystal lattice [29]. Among the three types of oxygen reported, I, II and III, Type I oxygen has lowest binding energy $(\sim 530 \mathrm{eV})$ and is bonded strongly to the

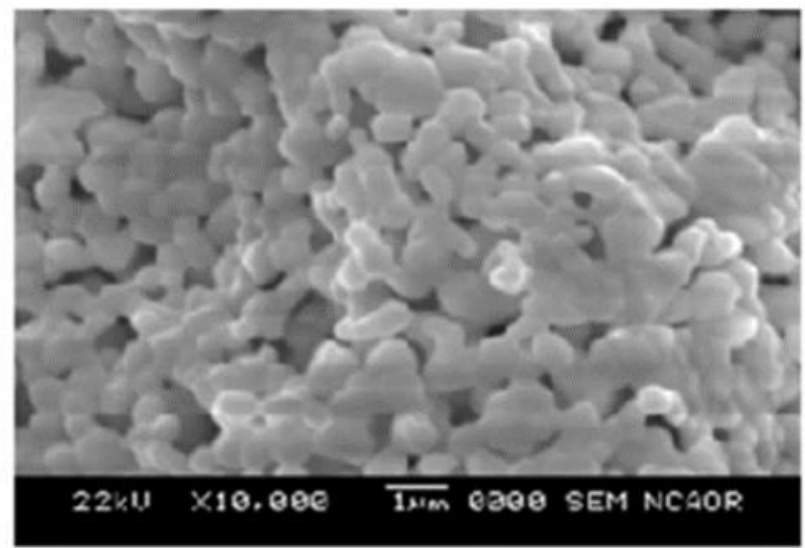

(b)

Figure 4. SEM Photographs of the compounds prepared at $650{ }^{\circ} \mathrm{C}$ (a) $\mathrm{Bi}_{2} \mathrm{MoO}_{6}$ and (b) $\mathrm{Bi}_{2} \mathrm{Moo}_{0.6} \mathrm{~W}_{0.4} \mathrm{O}_{6}$
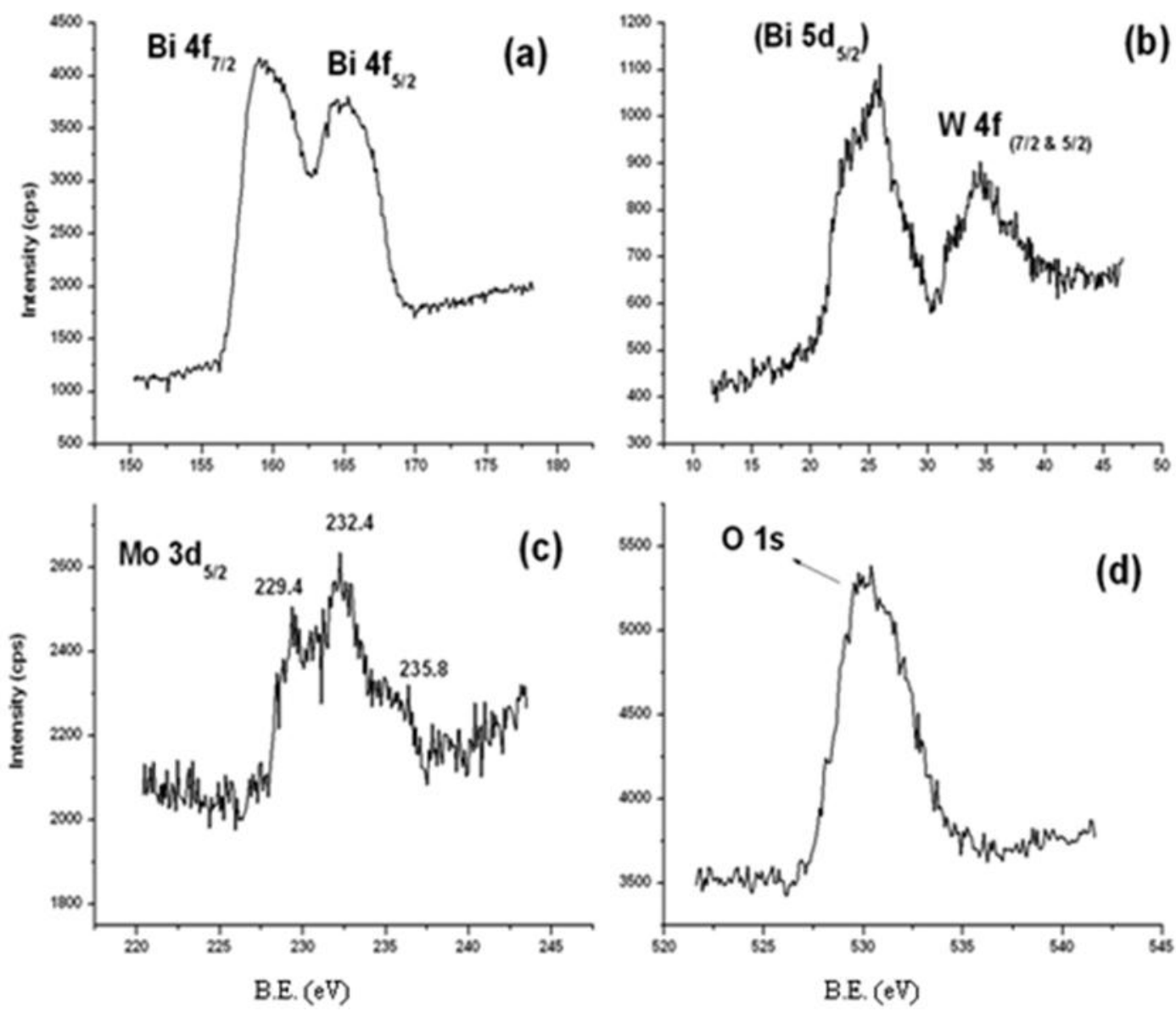

Figure 5. High resolution core level XPS spectra of $\mathrm{Bi}_{2} \mathrm{Mo}_{0.6} \mathrm{~W}_{0.4} \mathrm{O}_{6}$ (a) $\mathrm{Bi} 4 \mathrm{f}$ (b) $\mathrm{Bi} 5 \mathrm{~d}$, W $4 \mathrm{f}$ (c) $\mathrm{Mo} 3 \mathrm{~d}$ (d) $\mathrm{O} 1 \mathrm{~s}$. 
metal ions, type II is the oxygen which has highest binding energy $(\sim 533 \mathrm{eV})$ and is weakly bonded to the oxide surface whereas the type III oxygen with intermediate binding energy is considered as the measure of oxygen mobility. Broadening of the XPS spectra towards the higher binding energy values is indicative of decrease in the valence electron density around oxygen making its bonding with the Mo or $\mathrm{W}$ weak rendering more mobility to the lattice oxygen. As can be seen from the Figure 5 (d) the broadened XPS spectra indicate the presence of mobile oxygen species. This phenomenon is reported earlier by Rangel et al. [25] for similar compositions such as $\mathrm{Bi}_{2} \mathrm{Mo}_{0.75} \mathrm{~W}_{0.25} \mathrm{O}_{6}$ in explaining its enhanced catalytic activity for $\mathrm{CO}$ oxidation.

\section{4. $\mathrm{NH}_{3}$-TPD studies}

$\mathrm{NH}_{3}$ is used as a basic probe to elucidate the surface acid character of as prepared and acid enriched compounds. Figure 6 displays $\mathrm{NH}_{3}$ TPD studies on as prepared and acid enriched catalysts. As-prepared catalysts showed three distinct desorption peaks: (i) up to $300{ }^{\circ} \mathrm{C}$, (ii) between $350-475{ }^{\circ} \mathrm{C}$, and (iii) beyond $475{ }^{\circ} \mathrm{C}$. These can be considered as weak, mild, and strong acidic sites, respectively. The first peak showed higher intensity than the rest of the peaks observed at higher temperatures suggesting higher number of weak acid sites. In case of the acid enriched catalysts a steadfast distinction among the acidic sites was not observed, a very small hump in the weak acid region was observed followed by a broad and a relatively intense desorption of $\mathrm{NH}_{3}$ covering the temperature range from 250 to $500{ }^{\circ} \mathrm{C}$ sig-

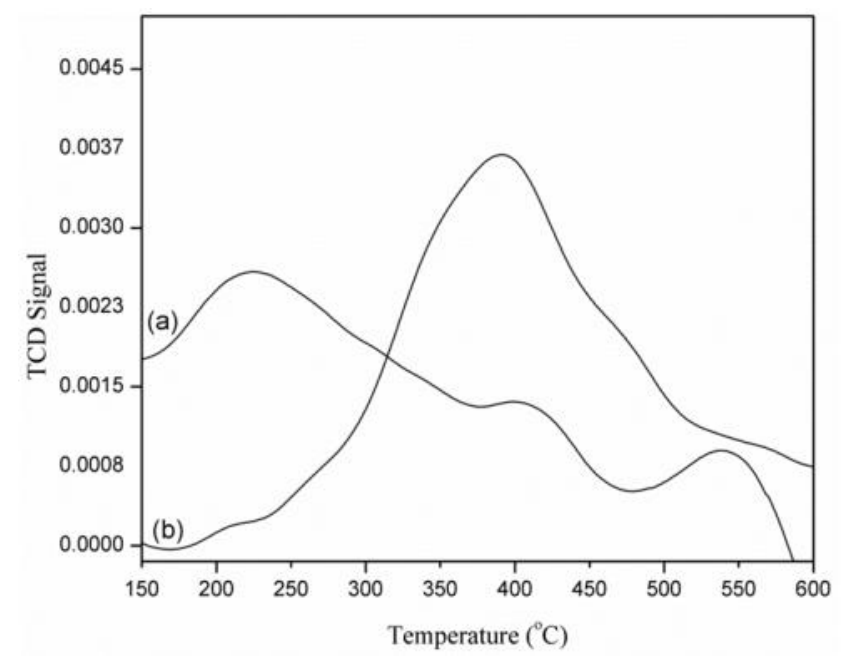

Figure 6. Ammonia temperature programmed desorption studies on (a) as prepared $\mathrm{Bi}_{2} \mathrm{Mo}_{0.6} \mathrm{~W}_{0.4} \mathrm{O}_{6}$, (b) acid enriched $\mathrm{Bi}_{2} \mathrm{Mo}_{0.6} \mathrm{~W}_{0.4} \mathrm{O}_{6}$ nifying a considerable decrease in the weak acidic sites and an increase in the mild and strong acidic sites. This observation proves that the acid enrichment has altered the surface acidic character of the catalysts.

\subsection{Catalytic activity}

The propylene to oxygen molar ratio used in this work was 1:1 which is stoichiometric for the partial oxidation of propylene to acrolein. Propylene conversion and product distribution over the as prepared catalysts is summarized in the Table 3. In case of all the catalysts the conversion increased with the increase in temperature. Significant propylene conversion was observed at temperatures higher than $300{ }^{\circ} \mathrm{C}$ on all the catalysts. $\mathrm{Bi}_{2} \mathrm{MoO}_{6}$ based catalysts are known to provide oxygen from the lattice for oxidation and at the same time harness oxygen from the feed gas to get re-oxidized [1]. The rate of this cycle is faster at higher temperatures and therefore, the higher yield of oxygenated products at higher temperatures.

The W-inserted catalysts were found to give better conversion than pristine $\mathrm{Bi}_{2} \mathrm{MoO}_{6}$. Among the prepared catalysts, $\mathrm{Bi}_{2} \mathrm{Mo}_{0.6} \mathrm{~W}_{0.4} \mathrm{O}_{6}$ showed highest propylene conversion. The mobility of oxygen atoms on catalytic surface should be greater in number for better catalytic partial oxidation. When slightly bigger $\mathrm{W}$ ion replaces $\mathrm{Mo}$ from $\mathrm{Bi}_{2} \mathrm{MoO}_{6}$ it is expected to increase the cell volume which is aptly supported by Reitveld refinements. The increase in the cell volume in turn has led to the weakening of Mo-O bond. This has helped for the easy removal of oxygen from the catalyst surface to form the partially oxygenated species like

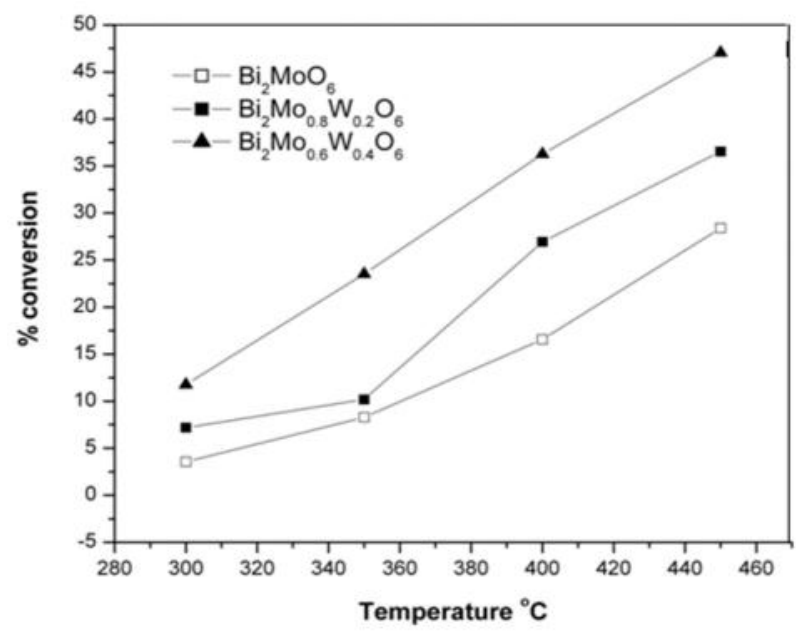

Figure 7. Catalytic activity results of the as prepared $\mathrm{Bi}_{2} \mathrm{Mo}_{1-\mathrm{x}} \mathrm{W}_{\mathrm{x}} \mathrm{O}_{6}$ catalysts for partial oxidation of propylene at different temperatures 
acrolein. Also in the XPS studies, the broadened O1s spectra have indicated the presence of mobile oxygen in the crystal lattice.

As observed from the Figure 8, all the acid enriched compounds gave higher propylene conversion than as prepared compounds. Product distribution over acid enriched compounds did not differ significantly from the as prepared compounds. The trend observed among the three catalysts for the propylene catalytic conversion was same as that for as prepared compounds. Maximum propylene conversion of $65 \%$ was observed in the case of acid enriched $\mathrm{Bi}_{2} \mathrm{Mo}_{0.6} \mathrm{~W}_{0.4} \mathrm{O}_{6}$. The higher conversion therefore points at the increased adsorption of propylene on the acid enriched surface. As the propylene oxidation starts above $300{ }^{\circ} \mathrm{C}$ mark it is essential to have a good number of adsorptive sites of sufficient strength on the catalyst surface for the better conversion. In these regards the increased amount of mild and strong acidic sites on acid enriched catalysts have played a major role in the increased adsorption of propylene leading to an improved conversion which is aptly supported by $\mathrm{NH}_{3}$ -

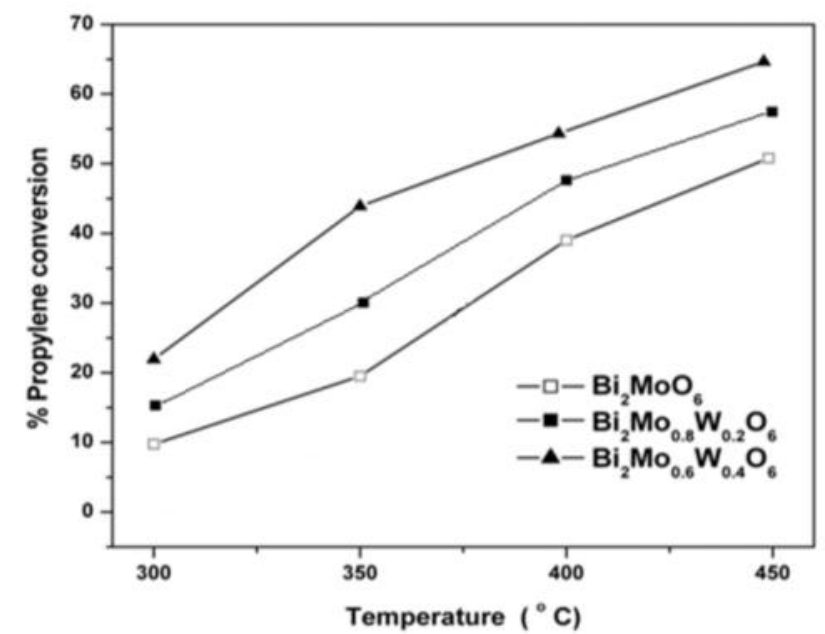

Figure 8. Catalytic activity results of the acid enriched $\mathrm{Bi}_{2} \mathrm{Mo}_{1-\mathrm{x}} \mathrm{W}_{\mathrm{x}} \mathrm{O}_{6}$ catalysts for partial oxidation of propylene at different temperatures
TPD studies. It must be also noted that the strong acidic sites can cause prolonged stay of the oxygenated compounds on the surface leading to further oxidation to carbon oxides resulting in the fall of selectivity towards the desired product, i.e. acrolein. In the present case the selectivity was not altered due to the increased surface acidity which proves that the surface acid enrichment has only increased the adsorptive sites on the surface without having any adverse effect on the selective oxidation.

\section{Conclusions}

Phase pure oxides were obtained by simple Pechini process. The orthorhombic Pca2 $2_{1}$ structure was maintained in all the cases as deduced using Rietveld method. W insertion has slightly increased the cell volume linearly. Porous, flake like morphology was confirmed from the SEM micrographs. XPS study confirmed the presence of expected oxidation states for all the elements except for the occurrence of Mo(IV). The broad O1s spectrum hinted towards the presence of mobile oxygen in the crystal lattice. The increase in the number of surface acidic sites after acid enrichment is aptly supported by $\mathrm{NH}_{3}$-TPD measurements. $\mathrm{W}$ insertion in $\mathrm{Bi}_{2} \mathrm{MoO}_{6}$ increased the catalytic performance. Moreover, the catalytic activity of $\mathrm{Bi}_{2} \mathrm{Mo}_{1-\mathrm{x}} \mathrm{W}_{\mathrm{x}} \mathrm{O}_{6}$ was found to be sensitive to the presence of surface acidic sites as acid enrichment has increased the catalytic conversion. Selectivity profiles of acid enriched catalysts were unaltered from as prepared compounds proving that the acid treatment has only affected the adsorptive sites on the surface without hampering the selectivity towards acrolein.

\section{Acknowledgements}

Authors are grateful to UGC-BSR \& CSIR, New Delhi, India for the financial support.

Table 3. Product distribution for propylene oxidation over as prepared $\mathrm{Bi}_{2} \mathrm{Mo}_{1-\mathrm{x}} \mathrm{W}_{\mathrm{x}} \mathrm{O} 6(\mathrm{x}=0.0,0.2,0.4)$

\begin{tabular}{|c|c|c|c|c|c|}
\hline \multirow{2}{*}{ Catalyst } & \multirow{2}{*}{$\begin{array}{l}\text { Temperature } \\
\left({ }^{\mathrm{O} C}\right)\end{array}$} & \multirow{2}{*}{$\begin{array}{c}\text { Propylene } \\
\text { Conversion } \\
(\%)\end{array}$} & \multicolumn{3}{|c|}{ Selectivity (\%) } \\
\hline & & & Acrolein & Acetaldehyde & Carbon oxides \\
\hline \multirow[t]{2}{*}{$\mathrm{Bi}_{2} \mathrm{MoO}_{6}$} & 400 & 15.0 & 98.0 & 1.0 & 1.0 \\
\hline & 450 & 28.0 & 95.0 & 2.0 & 3.0 \\
\hline \multirow[t]{2}{*}{$\mathrm{Bi}_{2} \mathrm{Mo}_{0.8} \mathrm{Mo}_{0.2} \mathrm{O}_{6}$} & 400 & 25.5 & 94.0 & 2.0 & 4.0 \\
\hline & 450 & 37.5 & 92.0 & 3.0 & 5.0 \\
\hline \multirow[t]{2}{*}{$\mathrm{Bi}_{2} \mathrm{Mo}_{0.6} \mathrm{~W}_{0.4} \mathrm{O}_{6}$} & 400 & 36.3 & 96.0 & 0.0 & 4.0 \\
\hline & 450 & 47.2 & 94.0 & 1.0 & 5.0 \\
\hline
\end{tabular}




\section{References}

[1] Callahan, J.L., Grasselli, R.K., Milberger, E.C., Strecker, H.A. (1970). Oxidation and Ammoxidatio of Propylene over Bismuth Molybdate Catalyst. Industrial \& Engineering Chemistry Product Research and Development, 9: 134-142.

[2] Bing, Z., Pei, S., Shishan, S., Xiexian, G. (1990). Cooperation between the $\mathrm{a}$ and $\mathrm{Y}$ Phases of Bismuth Molybdate in the Selective Oxidation of Propene. Journal of Chemical Society, Faraday Transactions, 86: 3145-3150.

[3] Le, M.T., Van Well, W.J.M., Stoltze, P., Driessche, I.V., Hoste, S. (2005). Synergy Effects between Bismuth Molybdate Catalyst Phases (Bi/Mo from 0.57 to 2) for the Selective Oxidation of Propylene to Acrolein. Applied Catalysis. A: General, 282: 189-194.

[4] Soares, A.P.V., Dimitrov, L.D., Oliveira, M.C.A., Portela, L.H.M.F., Grasselli, R.K. (2003). Synergy Effects between $B$ and y Bismuth Molybdates in the Selective Catalytic Oxidation of 1-Butene. Applied Catalysis. A: General, 253: 191-200.

[5] Grasselli, R.K. (2002). Fundamental Principles of Selective Heterogeneous Oxidation Catalysis. Topics in Catalysis, 21: 79-88.

[6] Le, M.T., Van Craenenbroeck, J., Van Driessche, I., Hoste, S. (2003). Bismuth Molybdate Catalysts Synthesized Using Spray Drying for the Selective Oxidation of Propylene. Applied Catalysis A: General, 249: 355-364.

[7] Burrington,, J.D., Kartisek C.T., Grasselli, R.K. (1984). Surface Intermediates in Selective Propylene Oxidation and Ammoxidation over Heterogeneous Molybdate and Antimonate Catalysts. Journal of Catalysis, 87: 363-380.

[8] Schuh, K., Kleist, W., Høj, M., Trouillet, V., Jensen, A.D., Grunwaldt, J.D. (2014). Onestep Synthesis of Bismuth Molybdate Catalysts via Flame Spray Pyrolysis for the Selective Oxidation of Propylene to Acrolein. Chemical Communications, 50: 15404-15406.

[9] Cruz, A.M., Alfaro, S.O., Cuellar, E.L., Mendez, U.O. (2007). Photocatalytic Properties of $\mathrm{Bi}_{2} \mathrm{MoO}_{6}$ Nanoparticles Prepared by an Amorphous Complex Precursor. Catalysis Today, 129: 194-199.

[10] Carson, D., Coudurier, G., Forissier, M., Vedrine, J.C., Laarif, A., Theobald, F. (1983). Synergy Effects in the Catalytic Properties of Bismuth Molybdates. Journal of Chemical Society, Faraday Transactions 1, 79: 1921-1929.

[11] Batist, P.A., Lippens, B.C., Schuit, G.C.A. (1966). The Catalytic Oxidation of 1-Butene over Bismuth Molybdate Catalysts: II. De- pendence of Activity and Selectivity on the Catalyst Composition. Journal of Catalysis, 5: 55-64.

[12] Krenzke, L.D., Keulks, G.W. (1980). The Catalytic Oxidation of Propylene: VIII: An Investigation of the Kinetics over $\mathrm{Bi}_{2} \mathrm{Mo}_{3} \mathrm{O}_{12}$, $\mathrm{Bi}_{2} \mathrm{MoO}_{6}$, and $\mathrm{Bi}_{3} \mathrm{FeMo}_{2} \mathrm{O}_{12}$. Journal of $\mathrm{Ca}$ talysis, 64: 295-302.

[13] Bettahar, M.M., Costentin, G., Savary, L., Lavalley, J.C. (1996) On the Partial Oxidation of Propane and Propylene on Mixed Oxide. Applied Catalysis A: General, 145: 1-48.

[14] Portela, M.F. (2001) Effect of Site Isolation on n-Butene Catalytic Oxidation and Isomerization over Bismuth Molybdates. Topics in $\mathrm{Ca}$ talysis, 15: 241-245.

[15] Ono, T., Nakajo, T., Hironaka, T. (1990) Kinetic Features and Lattice-Oxygen Participation in Propene Oxidation over Bi-Mo Oxide and Some Mo Oxide Catalysts. Journal of Chemical Society, Faraday Transactions, 86: 4077-4081.

[16] Hodnett, B.K. (2000). Heterogenous Catalytic Oxidation: Fundamental and Technological Aspects of the Selective and Total Oxidation of Organic Compounds. John Wiley \& Sons Ltd.

[17] Dadyburjor, D.B., Ruckenstein, E. (1990). Activation Energies to Characterize Ease of Removal of Various Kinds of Oxygen from Bismuth Molybdate. Journal of Catalysis, 63: 383-388.

[18] Burrington, J.D., Kartisek, C.T., Grasselli, R.K. (1983) Mechanism of Nitrogen Insertion in Ammoxidation Catalysis. Journal of Catalysis, 81: 489-498.

[19] Lin, C., Yu, M., Cheng, Z., Zhang, C., Meng, Q., Lin, J. (2008). Bluish-White Emission from Radical Carbonyl Impurities in Amorphous $\mathrm{Al}_{2} \mathrm{O}_{3}$ prepared via the Pechini-type Sol-Gel Processes. Inorganic Chemistry, 47: 49-55.

[20] Le, M.T., Van Well, W.J.M., Driessche, I.V., Hoste, S. (2004). Influence of Organic Species on Surface Area of Bismuth Molybdate Catalysts in Complexation and Spray Drying Methods. Applied Catalysis. A: General, 267: 227-234.

[21] Salker, A.V., Naik, S.J. (2009). Mechanistic Study of Acidic and Basic Sites for CO Oxidation over Nano Based $\mathrm{Co}_{2-\mathrm{x}} \mathrm{Fe}_{\mathrm{x}} \mathrm{WO}_{6}$ Catalysts. Applied Catalysis. B: Environmental, 89: 246254.

[22] Rodriguez-Carvajal, J. (2009) Fullprof: A Program for Rietveld, Profile Matching and Integrated Intensity Refinements for X-Ray and Neutron Data. Version 1.6. Laboratoire Leon Brillouin, Gif Sur Yvette, France 
[23] Teller, R.G., Brazdil, J.F., Grasselli, R.K., Jorgensen, J.D. (1984). The Structure of YBismuth Molybdate, $\mathrm{Bi}_{2} \mathrm{MoO}_{6}$, by Powder Neutron Diffraction. Acta Crystallographica C, 40: 2001-2005.

[24] Islam, M.S., Lazure, S., Vannier, R., Nowogrocki, G., Mairesse G. (1998) Structural and Computational Studies of $\mathrm{Bi}_{2} \mathrm{WO}_{6}$ Based Oxygen Ion Conductors. Materials Chemistry, 8: 655-660.

[25] Rangel, R., Bartolo-Perez, P., Martinez, E., Trejo-Cruz, X.A., Diaz, G., Galvan, D.H. (2012). Catalytic Activity and X-ray Photoelectron Spectroscopy Performance of $\mathrm{Bi}_{2} \mathrm{Mo}_{\mathrm{x}} \mathrm{W}_{(1-\mathrm{x})} \mathrm{O}_{6}$ solid-solutions. Catalysis Science and Technology, 2: 847-852.

[26] Zhang, F-J., Zhu, S-F., Xie, F-Z., Zhang, J., Meng, Z.D. (2013) Plate-on-plate Structured $\mathrm{Bi}_{2} \mathrm{MoO}_{6} / \mathrm{Bi}_{2} \mathrm{WO}_{6}$ Heterojunction with High Efficiently Gradient Charge Transfer for Decolorization of MB. Separation and Purification Technology, 113: 1-8.
[27] Le, M.T., Bac, L.H., Driessche, I.V., Hoste, S., Van well, W.J.M. (2008). The Synergy Effect Between Gamma and Beta Phase of Bismuth Molybdate Catalysts: Is there any Relation Between Conductivity and Catalytic Activity? Catalysis Today, 131: 566-571.

[28] Naik, S.J., Salker, A.V. (2010). Solid State Studies on Cobalt and Copper Tungstate Nano Materials. Solid State Sciences, 12: 2065-2072

[29] Jung, J.C., Lee, H., Kim, H., Chung, Y-M., Kim, T.J., Lee, S.J., Oh, S.H., Kim, Y.S., Song, I.K. (2008) Effect of Oxygen Capacity and Oxygen Mobility of Pure Bismuth Molybdate and Multicomponent Bismuth Molybdate on their Catalytic Performance in the Oxidative Dehydrogenation of n-Butene to 1,3-Butadiene. Catalysis Letters, 124: 262267. 